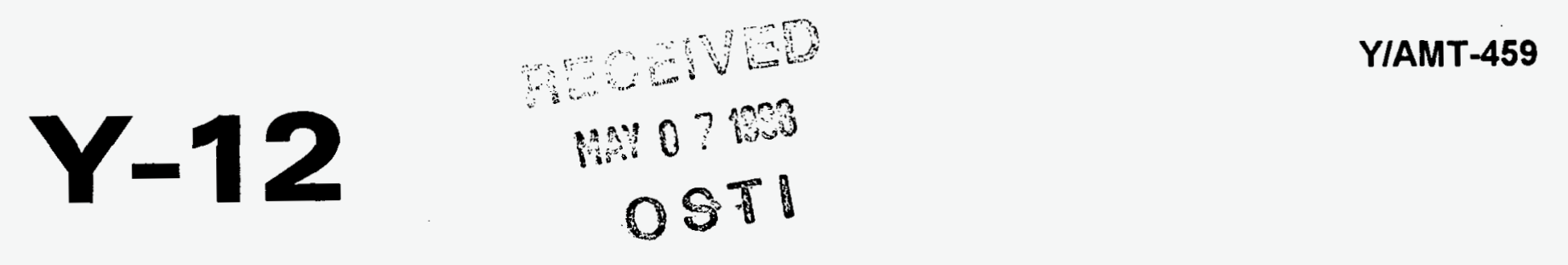

OAK RIDGE Y-12 PLANT
Project Accomplishment Summary for

Project Number 94-MULT-905-ES-4

\title{
SUPERPLASTIC FORMING OF STAINLESS STEEL AUTOMOTIVE COMPONENTS
}

\author{
Bob Bridges \\ Lockheed Martin Energy Systems, Inc. \\ John Elmer \\ Lawrence Livermore National Laboratory \\ Lawrence Carol
}

USCAR Low Emissions Technology Research and

Development Partnership

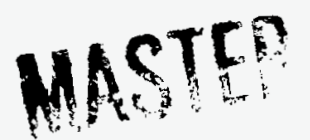

February 6, 1997

enc

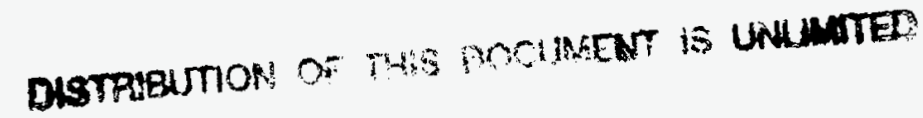

Approved for Public Release;

distribution is unlimited.

managed by

LOCKHEED MARTIN ENERGY SYSTEMS, INC.

for the

U.S. DEPARTMENT OF ENERGY 


\section{DISCLAIMER}

This report was prepared as an account of work sponsored by an agency of the United States Government. Neither the United States Government nor any agency thereof, nor any of their employees, makes any warranty, express or implied, or assumes any legal liability or responsibility for the accuracy, completeness, or usefulness of any information, apparatus, product, or process disclosed, or represents that its use would not infringe privately owned rights. Reference herein to any specific commercial product, process, or service by trade name, trademark, manufacturer, or otherwise, does not necessarily constitute or imply its endorsement, recommendation, or favoring by the United States Government or any agency thereof. The views and opinions of authors expressed herein do not necessarily state or reflect those of the United States Government or any agency thereof. 


\section{Project Accomplishment Summary}

Title:

DOE TTI Number

Superplastic Forming of Stainless Steel Automotive Components

CRADA Number:

94-MULT-905-ES-4

Partner:

Y1294-0293

USCAR Low Emissions Technology Research and Development

Partnership

\section{PURPOSE and BACKGROUND}

Exhaust emission standards are governmentally controlled standards, which are increasingly stringent, forcing alternate strategies to meet these standards. One approach to improve the efficiency of the exhaust emission equipment is to decrease the time required to get the catalytic converter to optimum operating temperature. To accomplish this, automotive manufacturers are using double wall stainless steel exhaust manifolds to reduce heat loss of the exhaust gases to the converter. The current method to manufacture double wall stainless steel exhaust components is to use a low-cost alloy with good forming properties and extensively form, cut, assemble, and weld the pieces. Superplastic forming (SPF) technology along with alloy improvements has potential at making this process more cost effective.

Lockheed Martin Energy Systems (LMES), Lawrence Livermore National Laboratory (LLNL) and USCAR Low Emission Partnership (LEP) worked under a Cooperative Research And Development Agreement (CRADA) to evaluate material properties, SPF behavior, and welding behavior of duplex stainless steel alloy for automotive component manufacturing. Battelle Pacific Northwest National Laboratory (PNNL) has a separate CRADA with the LEP to use SPF technology to manufacture a double wall stainless steel exhaust component. As a team these CRADAs developed and demonstrated a technical plan to accomplish making double wall stainless steel exhaust manifolds.

\section{DESCRIPTION}

This DP CRADA consisted of three tasks that were to be performed cooperatively by LMES and LLNL. LMES evaluated mechanical property characteristics of candidate alloys at various temperatures and strain rates to determine forming behavior, and LLNL determined alloy weldability and the effects of the heat effected zone (HAZ) of the weld. To begin the CRADA a commercially available duplex stainless steel, Superdux 65 (SD65), was acquired for testing and forming initial test parts. LMES cast and thermomechanically processed a couple of alloy test heats of duplex stainless steel to use in case a domestic material supplier was unavailable. Four U.S. stainless steel suppliers met with the CRADA participants at the end of project year one.

Task 1 - Alloy Selection and Concept Demonstration

The objective of this task was to select commercially available duplex stainless steel alloy from a U.S. stainless steel supplier, and to utilize SPF and laser welding techniques to fabricate a simple double wall pipe section. For concept demonstration, the double wall pipe section would be formed, tested, and evaluated for prototype acceptance. At the end of the first year a cost analysis study was to be performed to assess whether to continue the project using SPF manufacturing techniques to select some other forming method to manufacture components. 
Task 2 - Domestic SPF Alloy and Finite Element Analysis/Laser Welding Design In this task a U.S. stainless steel supplier was brought into the project to develop a method to commercially produce superplastic duplex stainless steel alloy. The laser cutting and welding involved: (1) the application of conventional lasers developed for cutting and welding of stainless steel, (2) metallurgical analysis of the weld quality, and (3) assessment of the metallurgical effects of the weld HAZ on the subsequent superplastic behavior of the alloy. Evaluation of the double wall pipe section was used to design more complex double wall exhaust components.

Task 3 - Project Demonstration for Automotive Production

During this task a prototype would have been fabricated with design techniques developed during the forming of double wall test pieces. A joint technical plan would transfer the technology developed to automotive designers. This demonstration plan would include the lessons learned from each participant to facilitate using SPF technology in future automotive component designs.

\section{SUMMARY of ACTIVITIES}

All of the milestones and deliverables were met in Tasks $1 \& 2$ with the exception of the cost analysis study. The cost analysis study began late in project year two as in-kind from the LEP and has not been concluded. Whether this technological approach is cost effective will not be answered during the DP supported CRADA. Armco Incorporated, a U.S. stainless steel supplier, partnered with the LEP at the beginning of project year two. Armco is providing a microduplex stainless steel alloy. The Armco alloy meets or exceeds the criteria stipulated by the project technical team. The Armco alloy is cost effective, exhibits superplastic behavior, welds easily, and is compatible with alloys used in other exhaust components. LMES was mechanically testing the Armco alloy to determine SPF parameters when DP funding ran out. The DP funding for project year two was withheld because of a DOE stipulation requiring an amendment to the CRADA contract. The amendment has been in the process for approval and signatures since March of 1996. Carry-over funds from project year one were depleted by June 1996, midway through alloy evaluation.

\section{BENEFITS to DOE}

The initial intent of this CRADA was for the DP labs to expand SPF technology in the area of alloy development and welding to benefit future weapon manufacturing. The CRADA was interrupted before such a goal could be completed. However, the collaborative effort of the project participants produced technical achievements that could have significant DP benefits. LMES was able to provided valuable forming parameters for test geometries under superplastic conditions, with both SD65 and the Armco alloy. Both alloys were tested at various temperatures at a constant strain of $1 \times 10^{-3} / \mathrm{s}$ and both proved to have excellent superplastic properties. For DP related applications, stainless steel alloys currently used could be substituted with the Armco alloy. Taking advantage of the superior SPF characteristics of the Armco alloy would eliminate annealing steps and reduce tooling requirements of current manufacturing techniques.

During the laser-welding endeavor LLNL discovered that these microduplex stainless steel alloys 
could be laser welded and then formed. During this study, no sigma formation was observed in the SD65 alloy. Lack of funding ended evaluating the presence and effect of sigma formation in the Armco alloy.

\section{ECONOMIC IMPACT}

The DP CRADA provided much of the design and technical groundwork for material qualification and joining techniques. PNNL is applying this technology through their CRADA for the LEP. Others companies have partnered with the LEP to commercialize this technology. The consumers will benefit from this project through automotive part suppliers providing a better product at a lower or equal cost. Taxpayers will have the benefit of cleaner air, from the LEP building automobiles that operate with lower exhaust emissions.

\section{PROJECT STATUS}

The project is being continued without the participation of LMES. To keep from jeopardizing the project the near term work, that was to be concluded by LMES, will have to be done by one of the other participants. The unfinished alloy development work includes, determining forming parameters at various rates and temperatures, the need for a post forming heat treatment, and determining the presence and effects of sigma formation.

\section{DOE FACILITY POINTS of CONTACT for PROJECT INFORMATION:}

Bob Bridges

Lockheed Martin Energy Systems

P. O. Box 2009

Oak Ridge, TN 37831-8096

(423) 574-2837, FAX (423) 574-2582

John Elmer

Lawrence Livermore National Laboratory

P. O. Box 808 , L-355

Livermore, CA 94551

(510) 422-6543 FAX (510) 423-7040

\section{PARTNER POINTS of CONTACT:}

Lawrence Carol

USCAR Low Emissions Technology Research and Development Partnership

AC Delco Systems World Headquarters

Mail Code: 485-301-150

4800 South Saginaw Street

P.O. Box 1360

Flint, Michigan 48501

(810) 257-5807 FAX (810) 257-7781

\section{TECHNOLOGY COMMERCIALIZATION}

Exhaust components are manufactured by automotive component suppliers and sold to the automotive companies. Technologically advanced products will be supplied through the same 


\section{DISTRIBUTION:}

Bob Bridges,

Ray Ford, MS-8084, 9203

Andy Stevens, DOE/OR, MS-8009-9704-2

Diane Bird, DOE DP-17

Bill Wilburn, MS-8015-9704-2

Y-12 Central Files, MS-8169 9711-5 (3 copies)

John Elmer, Lawrence Livermore National Laboratory, P. O. Box 808, L-355, Livermore, CA 94551 ( 3 copies)

Lawrence Carol, USCAR Low Emissions Technology Research and Development Partnership, AC Delco Systems World Headquarters, Mail Code: 485-301-150, 4800 South Saginaw Street, P.O. Box 1360, Flint, Michigan 48501, (5 copies) 
contractual agreements. Implementing this technology into commercial production will be proprietary between the LEP and their suppliers. 
Report Number (14) Y/AmT-.459

Publ. Date (11) $\frac{19970206}{\text { Sponsor Code (18) }} \frac{\text { DDE/DP, XF }}{U S-704, D O E / E R}$
UC Category (19) 